\title{
Potyvirus Genome-Linked Protein (VPg) Determines Pea Seed-Borne Mosaic Virus Pathotype-Specific Virulence in Pisum sativum
}

\author{
Karen E. Keller, ${ }^{1}$ I. Elisabeth Johansen, ${ }^{2}$ Robert R. Martin, ${ }^{1}$ and R. O. Hampton ${ }^{1}$ \\ ${ }^{1}$ USDA-ARS, Horticultural Crops Research Laboratory, 3420 N.W. Orchard Ave., and Department of Botany \\ and Plant Pathology, Oregon State University, Corvallis 97330, U.S.A.; ${ }^{2}$ Danish Institute of Plant and Soil \\ Science, 2800 Lyngby, Denmark \\ Accepted 9 October 1997.
}

\begin{abstract}
The mechanism of Pisum sativum pathotype-specific resistance to pea seed-borne mosaic potyvirus (PSbMV) was investigated and the coding region determinant of PSbMV virulence was defined. Homozygous recessive $s b m-1$ peas are unable to support replication of PSbMV pathotype 1 (P-1), whereas biochemically and serologically related pathotype $4(\mathrm{P}-4)$ is fully infectious in the $s b m-1 / s b m-1$ genotype. We were unable to detect viral coat protein or RNA with double antibody sandwich-enzyme-linked immunosorbent assay and reverse transcription-polymerase chain reaction in $s b m-1 / s b m-1$ P-1-inoculated protoplasts and plants. Lack of viral coat protein or RNA in P-1 transfected $s b m-1 / s b m-1$ protoplasts suggests that $s b m-1$ resistance is occurring at the cellular level and that inhibition of cell-to-cell virus movement is not the operating form of resistance. In addition, because virus products were not detected at any time post-inoculation, resistance must either be constitutive or expressed very early in the virus infection process. P-1-resistant peas challenged with fulllength, infectious P-1/P-4 recombinant clones demonstrated that a specific P-4 coding region, the 21-kDa, genome-linked protein (VPg), was capable of overcoming sbm-1 resistance, whereas clones containing the P-1 VPg coding region were noninfectious to $s b m-1 / s b m-1$ peas. VPg is believed to be involved in potyvirus replication and its identification as the PSbMV determinant of infectivity in $s b m-1 / s b m-1$ peas is consistent with disruption of an early $P-1$ replication event.
\end{abstract}

Several categories of plant virus resistance have been defined (Fraser 1988). Nonhost immunity occurs when every plant within a given species is resistant to a specific virus. Cultivar resistance results when individual plant cultivars or lines within a species are resistant to a specific virus. This type of resistance can be further subdivided into induced or constitutive resistance. Induced resistance is exemplified by

Corresponding author: Karen E. Keller; E-mail: kellerk@bcc.orst.edu

This article is in the public domain and not copyrightable. It may be freely reprinted with customary crediting of the source. The American Phytopathological Society, 1998. the hypersensitive response (HR) initiated by the dominant $N$ and $N^{\prime}$ resistance genes in tobacco in response to tobacco mosaic tobamovirus (TMV) replication. The TMV coat protein has been shown to be the elicitor of the HR in $N^{\prime}$ genotype tobacco plants (Culver and Dawson 1989) and some evidence suggests that the $126-\mathrm{kDa}$ replication protein of TMV is the elicitor of the HR in $N$ tobacco plants (Padgett and Beachy 1993). It is unknown whether TMV pathotype-specific Tm-1, $T m-2$, and $T m-2^{2}$ dominant tomato resistance genes are constitutive or induced. The functions of the $130-$ and $180-\mathrm{kDa}$ TMV replication proteins are inhibited in $T m-1$ plants (Watanabe et al. 1987; Meshi et al. 1988), whereas the Tm-2 and $T m-2^{2}$ allelic resistance genes appear to inhibit the function of the TMV 30-kDa movement protein (Meshi et al. 1989). Other virus/host interactions involving dominant genes have been demonstrated. Cowpea cv. Arlington encodes an inhibitor of the cowpea mosaic comovirus (CPMV) proteinase (Ponz et al. 1988), and the coat protein of potato virus X potexvirus (PVX) proved to be the determinant of the dominant $R x$ resistance in Solanum species (Kavanagh et al. 1992; Querci et al. 1995). In the homozygous state, the $y^{a}$ pepper resistance gene was shown to restrict movement of potato virus Y (PVY), the type member of the Potyviridae (potyvirus) family (Arroyo et al. 1996). In addition, the VPg protein of tobacco vein mottling potyvirus (TVMV) was shown to govern infectivity in homozygous recessive $v a$ tobacco plants (Nicolas et al. 1996). The mechanism of $v a$ resistance was also shown to be inhibition of virus cell-to-cell movement.

Pea seed-borne mosaic virus (PSbMV) is a member of the Potyviridae family of plant viruses, a family included in the picornavirus super-group along with other related plant and animal viruses (Koonin and Dolja 1993). Potyviruses have filamentous particles containing a single positive-sense RNA of approximately $10 \mathrm{~kb}$ that is polyadenylated at the $3^{\prime}$ terminus (Hari et al. 1979). The $5^{\prime}$ terminus of the genome is covalently linked to the virus-encoded VPg protein by a phosphodiester bond (Riechmann et al. 1989; Murphy et al. 1990, 1991). The genome contains one open reading frame that upon translation yields a single polyprotein that is subsequently cleaved into mature proteins by three virus-encoded proteinases, one of which is a multifunctional, 49-kDa protein consisting of a structural protein domain $(\mathrm{VPg})$ located at the $\mathrm{N}$ terminus (Shahabuddin et al. 1988; Riechmann et al. 1989; 
Murphy et al. 1990) and the proteinase domain (Pro) at the C terminus (Carrington and Dougherty 1987; Dougherty and Parks 1991). The 49-kDa proteinase is responsible for all six of the C-terminal polyprotein cleavage events, acting both in cis and trans (Riechmann et al. 1992). Various forms of the VPg have been found in association with potyviral genomes. Plum pox potyvirus (PPV) and tobacco vein mottling potyvirus (TVMV) RNAs are found associated with the VPg (Shahabuddin et al. 1988; Riechmann et al. 1989), while tobacco etch potyvirus RNAs are linked to either the VPg or VPg-Pro (Murphy et al. 1990; Carrington et al. 1993). Proteolytic processing events and protein functions of potyviruses have been reviewed (Riechmann et al. 1992).

Recessive pea genes that confer resistance to individual pathotypes of PSbMV have been used to define PSbMV pathotypes. Genes $s b m-1, s b m-3$, and $s b m-4$ are tightly linked on pea chromosome 6, and confer resistance to PSbMV pathotypes P-1, P-2, and P-4, respectively (Hagedorn and Gritton 1973; Provvidenti and Alconero 1988a, 1988b). PSbMV resistance gene sbm-2, located on chromosome 2, also confers resistance to P-2 (Provvidenti and Alconero 1988a).

The complete nucleic acid sequences of PSbMV P-1 isolate DPD1 (P1) and PSbMV P-4 isolate NY (P4) have been elucidated (Johansen et al. 1991, 1996b). Analysis of the two PSbMV pathotypes revealed $81 \%$ nucleotide and $88 \%$ amino acid identity. Full-length infectious clones of these two pathotypes have been constructed (Johansen 1996; Johansen et al. 1996a). Here we report on the use of P1/P4 recombinant viruses as tools to ascertain the $\mathrm{P} 1$ genomic region conferring inability of $\mathrm{P} 1$ to infect $s b m-1 / s b m-1$ pea genotypes. The mechanism of $s b m-1$ resistance to PSbMV-P1 virus infection was investigated by defining the point at which the P1 infection cycle was disrupted in the resistant genotype and identifying the PSbMV genomic determinant of pathogenicity.

\section{RESULTS}

\section{Detection of PSbMV-P1 in susceptible and resistant pea genotypes.}

Pea genotypes used in this study and their reaction to inoculation with PSbMV-P1 and -P4 are described in Table 1. PSbMV-P1- and PSbMV-P4-inoculated PI 269818, PI 193586 , or EF 680 peas were initially screened by double antibody sandwich-enzyme-linked immunosorbent assay (DASELISA) for evidence of systemic virus infection. P1 was not detected in noninoculated leaves of P1-challenged PI 269818 or PI 193586 plants. PI 269818 supported systemic infection of P4, whereas PI 193586 did not. Both P1 and P4 produced systemic infection in EF 680. P1 RNA and whole virus inoculated leaves of PI 269818 leaves were analyzed for presence of virus replication. In contrast to the susceptible control (EF 680) in which virus coat protein was detected in virioninoculated leaves by $24 \mathrm{~h}$ post-inoculation (hpi), PI 269818 revealed no virus coat protein up to $360 \mathrm{hpi}$, the duration of the experiment (Table 2).

In order to verify that virus was absent in PI 269818 leaves inoculated with P1, and that DAS-ELISA was not a limiting factor in detection of the virus in this genotype, P1-inoculated PI 269818 leaves were used to inoculate healthy EF 680 plants. DAS-ELISA failed to detect P1 antigen in EF 680 bioassay plants, leading us to conclude that either P1-inoculated
PI 269818 leaves lacked infectious PSbMV-P1 particles or PSbMV-P1 was present at too low a level for successful infection of EF 680 bioassay plants.

PSbMV pathotype-specific reverse transcription-polymerase chain reaction (RT-PCR; Kohnen et al. 1992, 1995) was used to assay for the presence of PSbMV RNA in total nucleic acid extracts from P1- or P4-inoculated PI 269818, PI 193586, and EF 680 leaves. No P1 RNA was detectable in PI 269818 or PI 193586 nucleic acid extracts by RT-PCR, but it was readily detectable in extracts from EF 680 (data not shown). P4 RNA was detected in both EF 680 and PI 269818 nucleic acid extracts, but not in those of PI 193586.

\section{Non-complementation of PSbMV-P1 by PSbMV-P4.}

In order to investigate the ability of P4 to complement P1 infectivity in trans, providing $\mathrm{P} 1$ the ability to infect PI 269818, we performed several co-inoculation trials. PSbMVP1 RNA was not detected by RT-PCR in total nucleic acid extracts from PI 269818 leaves that had been inoculated either simultaneously with P1 and P4 or first with P4 followed by P1 inoculation 7 days later. PSbMV-P4 RT-PCR product was detected in inoculated and systemically infected PI 269818 leaves from both treatments. Both P1 and P4 were detectable by RT-PCR in leaf extracts of inoculated EF 680 regardless of the inoculation pattern.

Investigation of PSbMV-P1 uncoating inhibition by sbm-1.

We explored the possibility that inhibition of viral uncoating was the mechanism of virus resistance in the PSbMVP1/sbm-1 system. PSbMV-P1 RNA, digested with Proteinase $\mathrm{K}$ in the presence of sodium dodecyl sulfate and extracted with phenol/chloroform, was used to inoculate both PI 269818 and EF 680 plants. Inoculated leaves were tested by DAS-

Table 1. Pisum genotypes and their reactions to PSbMV-P1 and PSbMVP4 inoculation

\begin{tabular}{lcccc}
\hline Pea line & $\begin{array}{c}\text { P1 resistance } \\
\text { gene }\end{array}$ & $\begin{array}{c}\text { Reaction } \\
\text { to } \text { P1 }^{\mathbf{a}}\end{array}$ & $\begin{array}{c}\text { P4 resistance } \\
\text { gene }\end{array}$ & $\begin{array}{c}\text { Reaction } \\
\text { to P4 }^{\mathbf{a}}\end{array}$ \\
\hline EF 680 & $S b m-1 / S b m-1$ & $\mathrm{~S}$ & $S b m-4 / S b m-4$ & $\mathrm{~S}$ \\
PI 269818 & $s b m-1 / s b m-1$ & $\mathrm{R}$ & $S b m-4 / S b m-4$ & $\mathrm{~S}$ \\
PI 193586 & $s b m-1 / s b m-1$ & $\mathrm{R}$ & $s b m-4 / s b m-4$ & $\mathrm{R}$ \\
\hline
\end{tabular}

${ }^{a} \mathrm{~S}$ represents a susceptible reaction to virus inoculation, $\mathrm{R}$ is resistant.

Table 2. Double antibody sandwich-enzyme-linked immunosorbent assay values for PSbMV-P1-inoculated pea leaves

\begin{tabular}{lccccc}
\hline & \multicolumn{2}{c}{ Experiment 1 $^{\mathbf{a}}$} & & \multicolumn{2}{c}{ Experiment 2 $^{\mathbf{b}}$} \\
\cline { 2 - 3 } \cline { 5 - 6 } Sampling time $^{\mathbf{c}}$ & EF 680 $^{\mathbf{d}}$ & PI 26981 & & EF 680 & PI 269818 \\
\hline 24 & 0.046 & 0.022 & & 0.003 & 0.000 \\
48 & 0.170 & 0.009 & & 0.002 & 0.005 \\
72 & 0.468 & 0.008 & & 0.000 & 0.003 \\
20 & 1.908 & 0.004 & & 0.008 & 0.000 \\
144 & 1.909 & 0.002 & & 0.136 & 0.006 \\
216 & 2.417 & 0.006 & & 0.366 & 0.000 \\
264 & 2.413 & 0.000 & & 0.688 & 0.006 \\
288 & 2.366 & 0.000 & & 1.106 & 0.005 \\
360 & 2.482 & 0.003 & & 1.719 & 0.002 \\
\hline
\end{tabular}

${ }^{a}$ Source of inoculum was sap from infected plant tissue.

${ }^{\mathrm{b}}$ Source of inoculum was purified viral RNA.

${ }^{c}$ Hours post-inoculation.

${ }^{\mathrm{d}} A_{405}$ mean values recorded $27 \mathrm{~h}$ after addition of substrate. 
ELISA for the presence of virus coat protein over a period of time ranging from 24 to 360 hpi (Table 2). No virus was detected in P1-inoculated PI 269818 pea leaves, whereas P1 was detectable in EF 680 plants at 6 days post-inoculation.

\section{Analysis of PSbMV-P1 transfected protoplasts.}

To explore the possible role of $s b m-1$ in restricting PSbMV$\mathrm{P} 1$ replication in individual cells, protoplasts were isolated from PI 269818 and EF 680 leaves. Indirect ELISA was used to detect viral coat protein in transfected protoplasts 3 to 4 days post-transfection. Repeatable experiments showed that both P1 and P4 were able to replicate in EF 680 transfected protoplasts (i.e., in one experiment $A_{405}$ values for P1 and P4 were 0.538 and 0.714 , respectively), while PI 269818 trans- fected protoplasts were only able to replicate P4 $\left(A_{405}\right.$ values were 0.092 and 0.279 for $\mathrm{P} 1$ and $\mathrm{P} 4$, respectively, in the same experiment). Because of a slight increase in the $A_{405}$ ELISA reading of P1 virus PI 269818 transfected protoplasts, isolated protoplasts were alternatively transfected with P1 RNA. Total RNA extracted from transfected protoplasts analyzed by RTPCR showed detectable P1 virus accumulation in susceptible EF 680 protoplasts only.

\section{Delineation of the PSbMV-P1 determinant of pathogenicity in $s b m-1 / s b m-1$ peas.}

Full-length infectious cDNA clones of PSbMV-P1, -P4, and others constructed for this study are illustrated in Figure 1A relative to the potyvirus genomic map. In repeated experiments,
A

Clone

P1

P4

P1 (P4 1-2259)

P1 (P4 8585-polyA)

P1 (P4 5817-polyA)

P4 (P1 2300-5874)

$\mathrm{P} 1$ ( $\mathrm{P} 4$ 6K2-VPg-Pro)

$\mathrm{P} 1(\mathrm{P} 4 \quad 6 \mathrm{~K} 2)$

P1 (P4 6K2/Pro)

$\mathrm{P} 4(\mathrm{P} 16 \mathrm{~K} 2)$

P4 (P1 VPg)

P1 (P4 VPg)

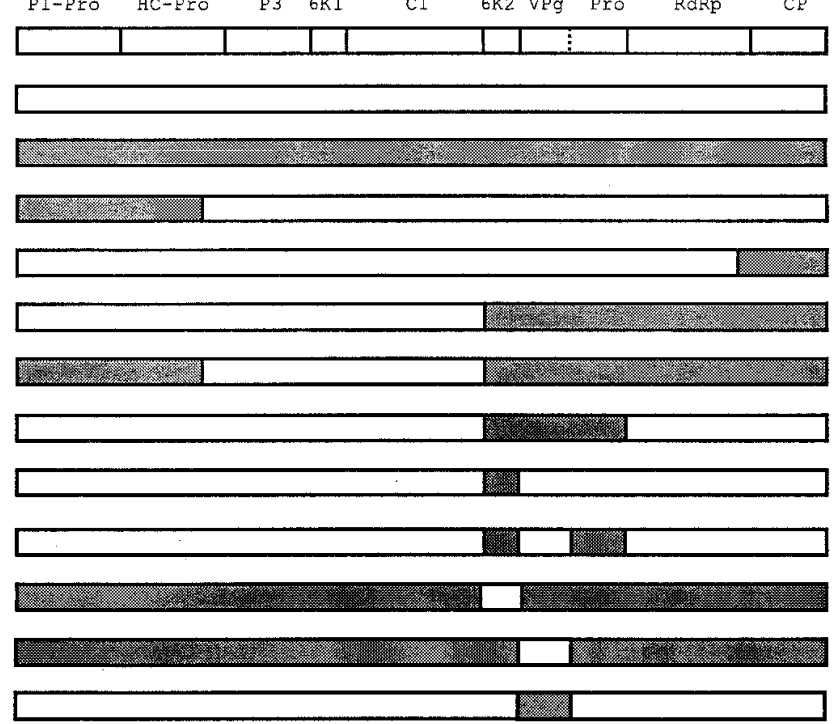

B

Pea Genotype Reaction to Virus Inoculation

$\underline{\text { EF680 }} \underline{\text { PI269818 }} \underline{\text { PI193586 }}$

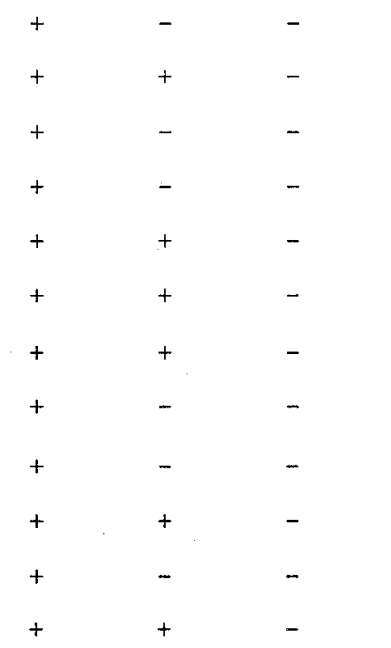

Fig. 1. Recombinant viruses and pea genotype reaction to each of these clones. A, Schematic of PSbMV P1/P4 full-length clones used to generate recombinant viruses. P1 segments are white; P4 segments are shaded. B, Pea genotype reaction to recombinant virus challenge. PSbMV genotype of EF 680 is $\mathrm{Sbm}-1 / \mathrm{Sbm}-1 \mathrm{Sbm}-4 / \mathrm{Sbm}$-4; that of PI 193586 is sbm-1/sbm-1 sbm-4/sbm-4. Differential genotype of PI 269818 is sbm-1/sbm-1 Sbm-4/Sbm-4. Noninoculated leaves from virus-challenged plants were tested by enzyme-linked immunosorbent assay at 10 to 14 days post-inoculation to verify resistance or susceptibility.

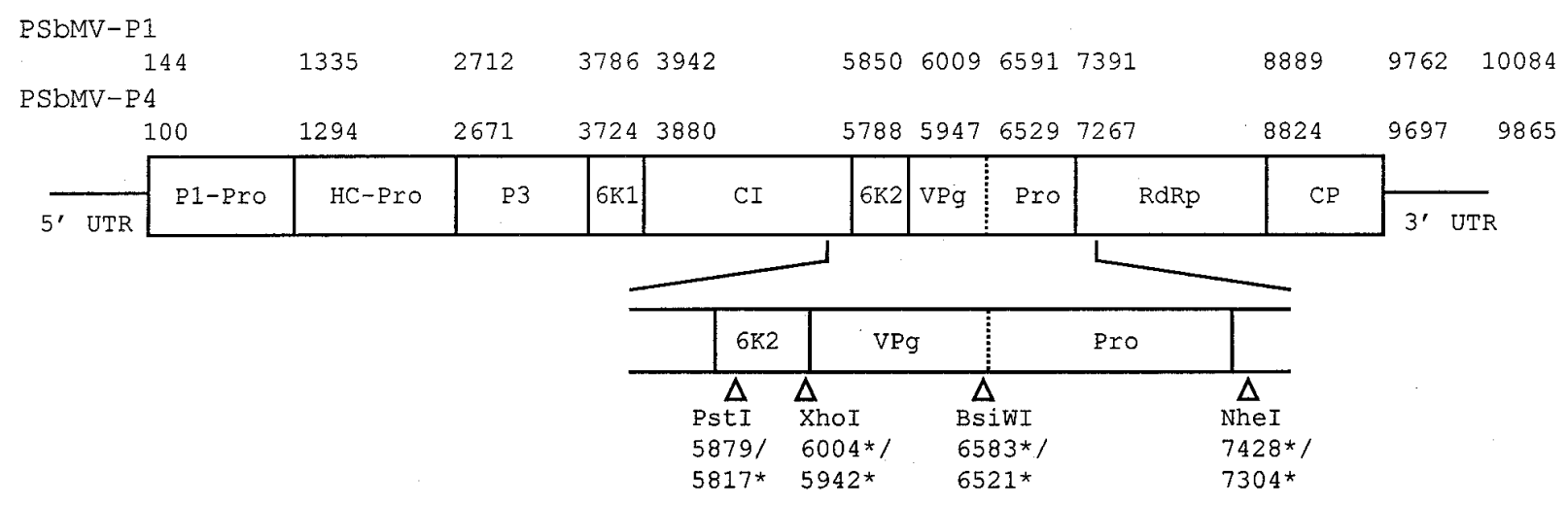

Fig. 2. Representation of the PSbMV genome with nucleotide numbers for the beginning of each coding region of pathotypes P1 and P4 listed above. Restriction sites (engineered*) utilized in the exchange of individual coding regions are illustrated below (P1/P4). 
all clones replicated to similar levels in EF 680 peas as tested by DAS-ELISA (data not shown). As with the P1 and P4 parental viruses, no clone was able to infect PI 193586 peas, while all clones were infectious to EF 680 plants (Fig. 1B). Screening of clones P1, P4, P1(P4 1-2259), P1(P4 8585-polyA), P1(P4 5817polyA), and $\mathrm{P} 4(\mathrm{P} 12300-5874)$ on PI 269818 peas demonstrated that the region encoding $6 \mathrm{~K} 2, \mathrm{VPg}$, Pro, and the putative RNAdependent RNA polymerase ( $\mathrm{RdRp}$ ) contained the determinant(s) of pathogenicity. This region was further analyzed by constructing recombinant clones P1(P4 6K2-VPg-Pro), P1(P4 6K2), P1(P4 6K2/Pro), P4(P1 6K2), P4(P1 VPg), and P1(P4 $\mathrm{VPg}$ ), each of which contains precise coding region exchanges in the 6K2, VPg, and Pro regions (Figs. 1A and 2). All recombinant viruses containing the P4 VPg domain were, like P4, able to infect plants of PI 269818, while recombinants containing the P1 VPg domain were noninfectious in $s b m-1 / s b m-1$ plants (Fig. $1 \mathrm{~A}$ and $\mathrm{B})$. DAS-ELISA analysis of the parental viruses, clones of the parental virus, and clones of parental viruses containing the exact VPg exchange demonstrated conclusively that the P1 VPg alone eliminated the ability of P4 recombinants to infect PI 269818, while P4 VPg, in any background, conferred the ability

Table 3. Double antibody sandwich-enzyme-linked immunosorbent assay values for PSbMV-P1-inoculated, PSbMV-P4-inoculated, and noninoculated pea leaves

\begin{tabular}{|c|c|c|c|c|c|c|}
\hline \multirow[b]{2}{*}{ Virus/clone $^{a}$} & \multicolumn{2}{|c|}{ EF 680} & \multicolumn{2}{|c|}{ PI 269818} & \multicolumn{2}{|c|}{ PI 193586} \\
\hline & $\mathbf{I}^{\mathbf{b}, \mathbf{c}}$ & $\mathbf{N I}^{\mathrm{d}}$ & $\mathbf{I}^{\mathbf{c}}$ & NI & I & NI \\
\hline $\mathrm{P} 1$ & $0.641^{\mathrm{e}}$ & 2.500 & 0.004 & 0.008 & 0.000 & 0.001 \\
\hline 1111 & 0.643 & 2.040 & 0.005 & 0.006 & 0.001 & 0.001 \\
\hline P4(P1 VPg) & 0.048 & 0.460 & 0.002 & 0.005 & 0.001 & 0.004 \\
\hline $\mathrm{P} 4$ & 0.074 & 0.420 & 0.958 & 0.446 & 0.002 & 0.004 \\
\hline 4444 & 0.574 & 0.747 & 0.508 & 0.244 & 0.006 & 0.006 \\
\hline P1(P4 VPg) & 0.338 & 2.427 & 0.564 & 1.566 & 0.006 & 0.006 \\
\hline
\end{tabular}

${ }^{\mathrm{a}} \mathrm{P} 1$ and $\mathrm{P} 4$ are parental viruses, while 1111 and 4444 are analogous, full-length, infectious clones.

b Inoculated leaves.

${ }^{\mathrm{c}}$ Inoculation-induced necrosis of $\mathrm{P} 4(\mathrm{P} 1 \mathrm{VPg})$ and $\mathrm{P} 4$ inoculated leaves is reflected in lower $A_{405}$ readings and may have influenced levels of virus in noninoculated leaves as well.

d Noninoculated leaves.

${ }^{\mathrm{e}} A_{405}$ readings were recorded $18 \mathrm{~h}$ after the addition of substrate. to infect this genotype (Fig. 1A and B; Table 3). Thus, we conclude that PSbMV VPg is the determinant of PSbMV pathogenicity to the $s b m-1 / s b m-1$ genotype of pea.

\section{Evaluation of $F_{1}$ progeny of EF $680 \times$ PI 269818 crosses.}

EF 680 peas were crossed with the PI 269818 line in order to obtain heterozygotes at the $S b m-1$ locus. The $S b m-1 / s b m-1$ plants were used to investigate the possibility that $s b m-1$ acts to positively inhibit PSbMV-P1 replication. Protoplasts isolated from these $F_{1}$ plants, along with protoplasts derived from the parental lines, were transfected with either P1 or P4 virus and subsequently with RNA. The hybrids showed the same degree of P1 RNA RT-PCR amplification as the parental P1transfected EF 680 protoplasts, whereas RNA isolated from P1 transfected PI 269818 protoplasts produced no amplification product (data not shown).

\section{DISCUSSION}

We have identified the PSbMV VPg as the virus pathotype determinant in the $s b m-1 / s b m-1$ genotype of pea. Our investigation into the mechanism of $s b m$-1-conferred resistance to $\mathrm{P} 1$ infection indicates that virus pathogenicity is disrupted by the $s b m-1$ gene at an early stage. Because we lack knowledge about the means by which the VPg functions in potyvirus pathogenesis and the role that the plant genes play in the virus life cycle we are unable to define the exact mechanism of sbm-1 resistance to PSbMV- P1. However, in addition to other work, this study allows us to theorize about possible PSbMV VPg interaction with $s b m-1$ and Sbm-1.

Since P1 genomic RNA, stripped of coat protein, is unable to establish either a local or systemic infection in the $s b m-1 /$ $s b m-1$ genotype, yet remains infectious to EF 680 plants, impeded uncoating of the viral genome is not the likely mechanism of constitutive immunity to P1. Because protoplasts isolated from PI 269818 do not support replication of P1, inhibited virus movement from initially infected cells, as in the case of the PVY/y ${ }^{a}$ and TVMV/va virus resistance mechanism, is also not the probable operating form of resistance in the $s b m-1 / s b m-1$ pea line.

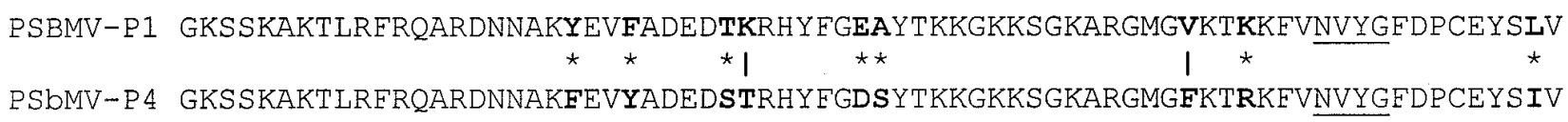

Fig. 3. Comparison of PSbMV-P1 and -P4 Vpg coding regions. Nonconserved amino acid residues are in bold; starred residues represent conservative, and vertical lines radical, amino acid differences. Conserved region representing the tyrosine binding site motif is underlined. 
Unlike eukaryotic mRNAs, members of the picornavirus super-group, including potyviruses, translate their genomic RNA in a cap-independent manner, with regions within the $5^{\prime}$ untranslated region acting as enhancers thought to bind proteins and/or ribosomes needed for initiation of translation (Carrington and Freed 1990; Nicolaisen et al. 1992; Basso et al. 1994). While we cannot rule out a VPg/sbm- 1 interaction in translational interference of P1 RNA, it would seem to be an unlikely cause of resistance due to the ability of genomic potyvirus RNA, lacking VPg, to remain infective (Hari 1981; our own data). Although VPg is not necessary for potyvirus translation to occur, there is some suggestion that VPg may bind eukaryotic initiation factor(s), thus inactivating the bound cellular protein or sequestering it in such a way that it is unavailable for mRNA translation (Wittmann et al. 1997). In either case, mRNA translation would be inhibited. Wang and Maule (1995) demonstrated that PSbMV inhibited pea gene expression, resulting in reduced protein accumulation, adding support to potyvirus inhibition of gene expression. Wittmann et al. (1997) also suggest that, alternatively, VPg binding of initiation factors could somehow be involved in virus replication. Host initiation factor participation in virus replication would seem more likely in the PSbMV model. Consistent with our findings, lack of recognition/interaction between a host component and P1 VPg could result in disruption of virus replication.

Unlike the situation in translation, covalent attachment of VPg to the potyvirus genome is essential for replication to occur and the VPg must be supplied in cis rather than in trans (Schaad et al. 1996), much as we have demonstrated by the unsuccessful rescue of $\mathrm{P} 1$ replication upon co-inoculation with $\mathrm{P} 4$ vs normal replication of the $\mathrm{P} 1$ recombinant containing the P4 VPg (i.e., clone P1(P4 VPg)) in PI 269818. Because VPg attachment could be a factor in PSbMV replication, we compared the probable P1 and P4 VPg linkage sites (Fig. 3). A tyrosine residue within the conserved TVMV VPg NMYG amino acid motif has been shown to be the amino acid that forms a covalent linkage via a phosphodiester bond to the $5^{\prime}$ terminus of the genome (Murphy et al. 1991). The lack of amino acid deviation between $\mathrm{P} 1$ and $\mathrm{P} 4$ in the similar PSbMV NVYG motif suggests that this site of genomic linkage is not a factor in $s b m-1$ pathogenicity.

There has been evidence suggesting that processing of the picornavirus-like polyproteins may regulate replication by controlling expression of gene products (Dougherty et al. 1989; Wimmer et al. 1993) and it has been shown that processing of the VPg-Pro site is essential for virus replication to occur (Carrington et al. 1993). However, differences between P1 and P4 amino acid sequences at the VPg-Pro cleavage site occur only at nonessential sites (Dougherty et al. 1988; 1989), leading us to conclude that these differences are not likely to be related to the effect of $s b m-1$ on P1 replication. Cleavage of the potyvirus $6 \mathrm{~K} 2-\mathrm{VPg}$ site is also essential for virus replication (Restrepo-Hartwig and Carrington 1994), but because the $6 \mathrm{~K} 2-\mathrm{VPg}$ site is conserved between P1 and P4, we did not investigate noncleavage of this $\mathrm{P} 1$ site in the resistant pea line. The three amino acids that constitute the $49-\mathrm{kDa}$, proteinase active site (Dougherty et al. 1989) and the amino acid thought to be essential for substrate binding (Bazan and Fletterick 1990) are also conserved between the two pathotypes, giving us additional evidence that polyprotein cleavage is not apt to be involved in the resistance mechanism (Fig. 3).
Hong et al. (1995) demonstrated that the potyvirus VPg interacts with the viral polymerase, while another study suggests that the polymerase interaction occurs between the VPg-Pro (Li et al. 1997). By analogy to another member of the picornavirus supergroup, poliovirus, potyvirus VPg may indeed act as a viral polymerase co-factor (Lama et al. 1995). This VPgpolymerase interaction strongly implies a role for VPg in replication. It is possible that the $s b m-1$ gene directly interferes with the VPg priming of replication. However, undiminished replication in the EF $680 \times$ PI $269818(\mathrm{Sbm}-1 / \mathrm{sbm}-\mathrm{l})$ crosses suggests that $s b m-1$ is not acting positively to inhibit P1 replication, leading us to favor a model in which P1 VPg and a cellular component needed for replication are unable to interact in the resistant $s b m-1 / s b m-1$ pea genotype.

\section{MATERIALS AND METHODS}

Pisum sativum (pea) genotypes and PSbMV pathotypes.

Seeds from USDA Pisum sativum L. Plant Introductions (PI) 269818 and 193586 were supplied by R. Provvidenti (New York State Agricultural Experiment Station, Cornell University, Geneva, New York). Seeds of pea cv. Early Freezer 680 were contributed by the Rogers/Sandoz Seed Company (Boise, ID). The P1 isolate DPD1 originated from a pea seed sample analyzed at the Danish Plant Directorate (Lyngby, Denmark). The P4 isolate NY was recovered from USDA Pisum accession PI 471128 and kindly provided by R. Provvidenti. Both P1 DPD1 and P4 NY sequences have been determined (Johansen et al. 1991, 1996b).

\section{Virus and RNA purification.}

Both pathotypes of PSbMV were purified from infected EF 680 pea plants, 3 weeks post-inoculation, following the method of Alconero et al. (1986). Viral RNA, free of both VPg and coat protein (Lindbo et al. 1993), was used for plant inoculation.

\section{Detection of PSbMV by DAS-ELISA and by RT-PCR.}

Immunoglobulin G (IgG) was purified from PSbMV rabbit antiserum (Hampton 1982). DAS-ELISA was used to detect PSbMV-P1, -P4, and P1/P4 recombinants in leaf extracts, as described by Kohnen et al. (1995). $A_{405}$ values for inoculated tissue/protoplasts reflect the background subtraction of mockinoculated samples. The methods of Kohnen et al. (1992, 1995) were used to perform PSbMV-specific RT-PCR. This method allowed $1 \mathrm{pg}$ of PSbMV RNA to be detected in combination with $1 \mu \mathrm{g}$ of total nucleic acid extracted from pea, while $1 \mathrm{fg}$ could be amplified from solutions that contained PSbMV RNA alone.

\section{PSbMV complementation of P1 by P4 in PI 269818 peas.}

In three separate experiments, PI 269818 plants were inoculated with P4 followed by inoculation with P1 7 days later. Alternatively, PI 269818 plants were co-inoculated with P1 and P4. In all cases, P1- or P4-infected EF 680 tissues served as inoculum sources. Both inoculated and noninoculated leaves from the same plant were tested for the presence of P1 and P4 RNA by pathotype-specific RT-PCR (Kohnen et al. 1992, 1995). Inoculations with P4 followed by P1 were assayed 5 dpi for P1 and 12 dpi for P4, whereas P1/P4 inoculated plants were tested 5 dpi. 
Preparation, transfection, and analysis of protoplasts.

Protoplasts were isolated from healthy EF 680 and PI 269818 pea seedlings and transfected with $200 \mu$ g of virus or $70 \mu \mathrm{g}$ of RNA by the method of Demler et al. (1993). After transfection, protoplasts were allowed to incubate for 3 to 4 days at $25^{\circ} \mathrm{C}$. One half of the cells were concentrated and tested by indirect ELISA (Hampton et al. 1992). $A_{405}$ values were recorded with an EL309 Microplate Autoreader (BioTek, Winooski, VT). The remaining protoplasts were prepared for RT-PCR by the method of Kohnen et al. (1992, 1995).

\section{Construction and analysis of PSbMV P1-P4 recombinant cDNA clones.}

Natural or engineered (Fig. 2; Kunkel et al. 1987) common restriction sites were used to construct hybrid P1/P4 cDNA clones (Fig. 1A). Oligonucleotides containing desired nucleotide changes were made by the Oregon State University Central Service Laboratory with an ABI Model 380A DNA synthesizer (Perkin-Elmer, Norwalk, CT). BamHI, PstI, XhoI, and $B s i$ WI were silent, whereas introduction of the NheI site resulted in a glycine to alanine codon change in both P1 and P4. Locations of restriction sites used in the interchanges are shown in Figure 2. BamHI, PstI, and HindIII sites were used to assemble the four hybrids P1(P4 1-2259), P1(P4 8585polyA), P1(P4 5812-polyA), and P4(P1 2300-5874) (Johansen et al. 1996a). Common XhoI, BsiWI, and NheI sites were used to assemble all other clones. The virus sequences of all clones except $\mathrm{P} 4(\mathrm{P} 16 \mathrm{~K} 2), \mathrm{P} 4(\mathrm{P} 1 \mathrm{VPg})$, and $\mathrm{P} 1(\mathrm{P} 4 \mathrm{VPg})$ were assembled downstream from the T7 promoter of pT7E19(+) (Petty 1988). The clones utilizing the T7 promoter were linearized with a unique $X b a \mathrm{I}$ site $3^{\prime}$ to the poly(A) tail prior to transcription. Capped transcripts were generated with the Ambion (Austin, TX) mMessage mMachine in vitro transcription kit. Clones P4(P1 6K2), P4(P1 VPg), and P1(P4 $\mathrm{VPg}$ ) were placed under control of the cauliflower mosaic virus $35 \mathrm{~S}$ promoter and nopaline synthetase terminator in $\mathrm{pA}$ GUS1 (Johansen 1996). Inoculated plants were assayed for presence of viral coat protein by DAS-ELISA 14 dpi.

\section{ACKNOWLEDGMENTS}

We would like to express thanks to Bill Dougherty and Dawn Parks for their suggestions and assistance. Also, we would like to thank Paul Kohnen and Kathy Garrett for their help with key aspects of this project. Thanks also to Rosie Provvidenti for kindly providing Pisum genotypes PI 269818 and PI 193586 and Valerian Dolja for his assistance and advice.

\section{LITERATURE CITED}

Alconero, R. Provvidenti, R., and Gonsalves, D. 1986. Three pea seedborne mosaic virus pathotypes from pea and lentil germ plasm. Plant Dis. 70:783-786.

Arroyo, R., Soto, M. J., Martínez-Zapater, J. M., and Ponz, F. 1996. Impaired cell-to-cell movement of potato virus $\mathrm{Y}$ in pepper plants carrying the $y^{a}\left(p r 2^{1}\right)$ resistance gene. Mol. Plant-Microbe Interact. 9:314318.

Basso, J., Dallaire, P., Charest, P. J., Devantier, Y., and Laliberte, J.-F. 1994. Evidence for an internal ribosome entry site within the $5^{\prime}$ nontranslated region of turnip mosaic potyvirus RNA. J. Gen. Virol. 75: 3157-3165.

Bazan, J. F., and Fletterick, R. J. 1990. Structural and catalytic models of trypsin-like viral proteases. Semin. Virol. 1:311-322.

Carrington, J. C., and Dougherty, W. G. 1987. Small nuclear inclusion protein encoded by a plant potyvirus genome is a protease. J. Virol.
64:1590-1597.

Carrington, J. C., and Freed, D. D. 1990. Cap-independent enhancement of translation by a plant potyvirus $5^{\prime}$ nontranslated region. J. Gen. Virol. 64:1590-1597.

Carrington, J. C., Haldeman, R., Dolja, V. V., and Restrepo-Hartwig, M. A. 1993. Internal cleavage and trans-proteolytic activities of the VPgproteinase (NIa) of tobacco etch potyvirus in vivo. J. Virol. 67:69957000 .

Culver, J. N., and Dawson, W. O. 1989. Point mutations in the coat protein gene of tobacco mosaic virus induce hypersensitivity in Nicotiana sylvestris. Mol. Plant-Microbe Interact. 2:209-213.

Demler, S. A., Rucker, D. G., and de Zoeten, G. A. 1993. The chimeric nature of the genome of pea enation mosaic virus: The independent replication of RNA 2. J. Gen. Virol. 74:1-14.

Dougherty, W. G., Carrington, J. C., Cary, S. M., and Parks, T. D. 1988. Biochemical and mutational analysis of a plant virus polyprotein cleavage site. EMBO J. 7:1281-1287.

Dougherty, W. G., Cary, S. M., and Parks, T. D. 1989. Molecular genetic analysis of a plant polyprotein cleavage site: A model. Virology 171: 356-364.

Dougherty, W. G., and Parks, T. D. 1991. Post-translational processing of the tobacco etch virus 49-kDa small nuclear inclusion polyprotein: Identification of an internal cleavage site and delimitation of VPg and proteinase domains. Virology 183:449-456.

Fraser, R. S. S. 1988. Virus recognition and pathogenicity: Implications for resistance mechanisms and breeding. Pestic. Sci. 23:267-275.

Hagedorn, D. J., and Gritton, E. T. 1973. Inheritance of resistance to the pea seed-borne mosaic virus. Phytopathology 63:1130-1133.

Hampton, R. O. 1982. Incidence of the lentil strain of pea seedborne mosaic virus as a contaminant of Lens culinaris germ plasm. Phytopathology 72:695-698.

Hampton, R. O., Albrechtsen, S. E., and Mathur, S. B. 1992. Seed health (viruses) of Vigna unguiculata selections from developing countries. Seed Sci. Technol. 20:23-38.

Hari, V. 1981. The RNA of tobacco etch virus: Further characterization and detection of protein linked to the RNA. Virology 112:391-399.

Hari, V., Siegel, A., Rozek, C., and Timberlake, W. E. 1979. The RNA of tobacco etch virus contains poly(A). Virology 92:568-571.

Hong, Y., Levay, K., Murphy, J. F., Klein, P. G., Shaw, J. G., and Hunt, A. G. 1995. A potyvirus polymerase interacts with the viral coat protein and VPg in yeast cells. Virology 214:159-166.

Johansen, I. E. 1996. Intron insertion facilitates amplification of cloned virus cDNA in Escherichia coli while biological activity is reestablished after transcription in vivo. Proc. Natl. Acad. Sci. USA 93: 12400-12405.

Johansen, I. E., Dougherty, W. G., Keller, K. E., Wang, D., and Hampton, R. O. 1996a. Multiple viral determinants affect seed transmission of pea seedborne mosaic virus in Pisum sativum. J. Gen. Virol. 77: 3149-3154.

Johansen, I. E., Keller, K. E., Dougherty, W. G., and Hampton, R. O. 1996b. Biological and molecular properties of a pathotype P-1 and a pathotype P-4 isolate of pea seed-borne mosaic virus. J. Gen. Virol. 77:1329-1333.

Johansen, E., Rasmussen, O. F., Heide, M., and Borkhardt, B. 1991. The complete nucleotide sequence of pea seedborne mosaic virus RNA. J. Gen. Virol. 72:2625-2632.

Kavanagh, T., Goulden, M., Santa Cruz, S., Chapman, S., and Baulcombe, D. 1992. Molecular analysis of a resistance-breaking strain of potato virus X. Virology 189:609-617.

Kohnen, P. D., Dougherty, W. G., and Hampton, R. O. 1992. Detection of pea seedborne mosaic potyvirus by sequence specific enzymatic amplification. J. Virol. Methods 37:253-258.

Kohnen, P. D., Johansen, I. E., and Hampton, R. O. 1995. Characterization and molecular detection of the P4 pathotype of pea seedborne mosaic potyvirus. Phytopathology 85:789-793.

Koonin, E. V., and Dolja, V. V. 1993. Evolution and taxonomy of positive-strand RNA viruses: Implications of comparative analysis of amino acid sequences. Crit. Rev. Biochem. Mol. Biol. 28:375-430.

Kunkel, T. A., Roberts, J. D., and Zakour, R. A. 1987. Rapid and efficient site-specific mutagenesis without phenotypic selection. Methods Enzymol. 154:367-382.

Lama, J., Sanz, M. A., and Rodriguez, P. L. 1995. A role for 3AB protein in poliovirus genome replication. J. Biol. Chem. 270:1443014438 . 
Li, X. H., Valdez, P., Olvera, R. E., and Carrington, J. C. 1997. Functions of the tobacco etch virus RNA polymerase (NIb): Subcellular transport and protein-protein interaction with $\mathrm{VPg} /$ proteinase (NIa). J. Virol. 71:1598-1607.

Lindbo, J. A., Silva-Rosales, L., Proebsting, W. M., and Dougherty, W. G. 1993. Induction of highly specific antiviral state in transgenic cells. Proc. Natl. Acad. Sci. USA 92:457-461.

Meshi, T., Motoyoshi, F., Adachi, A., Watanabe, Y., Takamatsu, N., and Okada, Y. 1988. Two concomitant base substitutions in the putative replicase genes of tobacco mosaic virus confer the ability to overcome the effects of tomato resistance gene, Tm-1. EMBO J. 7:1575-1581.

Meshi, T., Motoyoshi, F., Maeda, T., Yoshiwoka, S., Watanabe, H., and Okada, Y. 1989. Mutations in the tobacco mosaic virus $30-\mathrm{kDa}$ protein gene overcome Tm-2 resistance in tomato. Plant Cell 1:515-522.

Murphy, J., Rhoads, R., Hunt, A. G., and Shaw, J. G. 1990. The VPg of tobacco etch virus RNA is the 49-kDa proteinase or the $\mathrm{N}$-terminal 24-kDa part of the proteinase. Virology 178:285-288.

Murphy, J., Rychlik, W., Rhoads, R. E., Hunt, A. G., and Shaw, J. G. 1991. A tyrosine residue in the small nuclear inclusion protein of tobacco vein mottling virus links the VPg to the viral RNA. J. Virol. 65:511-513.

Nicolaisen, M., Johansen, E., Poulsen, G. B., and Borkhardt, B. 1992. The $5^{\prime}$ untranslated region from pea seedborne mosaic potyvirus RNA as a translational enhancer in pea and tobacco protoplasts. FEBS Lett. 303:169-172.

Nicolas, O., Pirone, T. P., and Hellmann, G. M. 1996. Construction and analysis of infectious transcripts from a resistance-breaking strain of tobacco vein mottling potyvirus. Arch. Virol. 141:1535-1552.

Padgett, H. S., and Beachy, R. N. 1993. Analysis of a tobacco mosaic virus strain capable of overcoming $N$ gene-mediated resistance. Plant Cell 5:577-586.

Petty, I. T. D. 1988. A plasmid vector for cloning directly at the transcription initiation site of a bacteriophage T7 promoter. Nucleic Acids Res. 16:8738.

Ponz, F., Glascock, C. B., and Bruening, G. 1988. An inhibitor of polyprotein processing with the characteristics of a natural virus resistance factor. Mol. Plant-Microbe Interact. 1:25-31.
Provvidenti, R., and Alconero, R. 1988a. Inheritance of resistance to a lentil strain of pea seed-borne mosaic virus in Pisum sativum. J. Hered. 79:45-47.

Provvidenti, R., and Alconero, R. 1988b. Inheritance of resistance to a third pathotype of pea seed-borne mosaic virus in Pisum sativum. J. Hered. 79:76-77.

Querci, M., Baulcombe, D. C., Goldbach R. W., and Salazar, L. F. 1995. Analysis of the resistance-breaking determinants of potato virus $\mathrm{X}$ (PVX) strain HB on different potato genotypes expressing extreme resistance to PVX. Phytopathology 85:1003-1010.

Restrepo-Hartwig, M. A., and Carrington, J. C. 1994. The tobacco etch potyvirus 6-kilodalton protein is membrane associated and involved in viral replication. J. Virol. 64:2967-2975.

Riechmann, J. L., Lain, S., and Garcia, J. A. 1989. The genome-linked protein and 3' RNA sequence of plum pox potyvirus. J. Gen. Virol. 70:2785-2789.

Riechmann, J. L., Lain, S., and Garcia, J. A. 1992. Highlights and prospects of potyvirus molecular biology. J. Gen. Virol. 73:1-16.

Schaad, M. C., Haldeman-Cahill, R., Cronin, S., and Carrington, J. C. 1996. Analysis of the VPg-proteinase (NIa) encoded by tobacco etch potyvirus: Effects of mutations on the subcellular transport, proteolytic processing, and genome amplification. J. Virol. 70:7039-7048.

Shahabuddin, M., Shaw, J. G., and Rhoads, R. E. 1988. Mapping of the tobacco vein mottling virus VPg cistron. Virology 163:635-637.

Wang, D., and Maule, A. J. 1995. Inhibition of host gene expression associated with plant virus replication. Science 267:229-231.

Watanabe, Y., Kishibayashi, N., Motoyoshi, F., and Okada, Y. 1987. Characterization of $T m-1$ gene action on replication of common isolates and a resistance-breaking isolate of TMV. Virology 161: 527-532.

Wittmann, S., Chatel, H., Fortin, M. G., and Laliberte, J.-F. 1997. Interaction of the viral protein genome linked of turnip mosaic potyvirus with the translational eukaryotic initiation factor (iso) 4E of Arabidopsis thaliana using the yeast two-hybrid system. Virology 234:8492.

Wimmer, E., Hellen, C. U., and Cao, X. 1993. Genetics of poliovirus. Annu. Rev. Genet. 27:353-436. 